\title{
PENGEMASAN ATRAKSI WISATA SUSUR SUNGAI KLEGUNG MELALUI PENDEKATAN POTENSI WISATA
}

\author{
Arif Dwi Saputra
}

Sekolah Tinggi Pariwisata AMPTA, Yogyakarta, Indonesia, email: dwisaputra.arif@yahoo.co.id

\begin{abstract}
ABSTRAK
Histori Artikel

Submitted:

01 Februari 2020

Reviewed:

24 Februari 2020

Accepted:

05 Maret 2020

Published:

15 Mei 2020

Pengembangan wisata berbasis masyarakat merupakan peluang untuk mengembangkan daya tarik wisata yang hampir tidak diketahui oleh wisatawan pada umumnya, dan akan mengurangi dampak sosial budaya bagi masyarakat tersebut. Adanya potensi sungai Klegung yang membentuk aliran sungai serta kekayaan ekosistem tepi sungainya yang masih alami membuat masyarakat berinisiatif untuk membuka destinasi wisata guna memberi manfaat baik secara ekonomi maupun bagi keberlangsungan sumber daya air yang ada. Selain itu belum adanya pendataan potensi ekowisata yang ada, membuat pengelola dalam hal ini masyarakat belum memaksimalkan potensi untuk dapat diwujudkannya ekologi wisata. Penelitian yang telah dilakukan menggunakan mixed Method ini bertujuan untuk menganalisis potensi wisata di destinasi Sungai Klegung sebagai destinasi wisata alam, yaitu potensi SDM; Kebudayaan; Flora dan Fauna, serta Atraksi yang sesuai dengan karateristik Padukuhan Klegung. Setelah diketahui potensi yang ada kemudian dibuatkan kemasan atraksi yang menarik dan sesuai.
\end{abstract}

Kata Kunci: Potensi, Ekowisata, Kemasan Atraksi

\section{PACKAGING TOURISM ATTRACTIONS ALONG THE KLEGUNG RIVER THROUGH THE APPROACH OF TOURISM POTENTIAL}

\begin{abstract}
Community-based ecotourism development is an opportunity to developtourist attractions that are almost unknown to tourists in general, and will reduce the social cultural impact for the community. The potential of Klegung river that forms the river flow and the natural wealth of its riverside ecosystemmakes the community take theintiative to open tourismdestinations to providebenefits both economically and for the sustainabilityof existing water resources. The research that has been conducted using qualitative descriptive method aims to analyze the potential of human resources, culture, flora and fauna, and attraqctions in accordance with the charateristics of Padukuhan Klegung. Having known the potential, then made attractive and appropriate attraction packages. keywords are required for computerization. Research and abstract title search made easy with these keywords.
\end{abstract}

Keywords : Potential, ecotourism, packaing of attractions. 


\section{PENDAHULUAN}

Pariwisata merupakan salah satu sektor industri yang sangat kompleks dan bersifat multidimensi. Sektor yang termasuk dalam industri pariwisata tersebut yaitu meliputi ekonomi, sosial, budaya, properti, jasa, serta berbagai sektor lain yang mendukung jalannya kegiatan kepariwisataan. Berkembangnya industri pariwisata di suatu negara akan dapat menarik sektor lain untuk berkembang. Hal ini dikarenakan industri pariwisata akan memerlukan berbagai produk penunjang seperti produk pertanian, peternakan, perkebunan hingga kerajianan tangan rakyat. Tak terkecuali Indonesia sebagai Negara yang sedang berkembang turut meramaikan perkembangan industri pariwisata.

Sebagai Negara yang turut mengambil manfaat dari kegiatan industri pariwisata, Indonesia memiliki berbagai potensi. Luas daratan Indonesia (sekitar 192,3 juta Ha) hanya mencakup $1,3 \%$ dari luas daratan dunia, namun karena keadaan alamnya yang khas, merupakan tempat hidup berbagai jenis tumbuhan dan satwa. Tumbuhan berbunga memiliki $10 \%$ dari kekayaan tumbuhan dunia. Dari kekayaan alam satwa maka Indonesia memiliki sekitar $12 \%$ dari jenis mamalia yang ada di dunia, $16 \%$ dari jenis raptilia dan $17 \%$ jenis Aves serta serta $25 \%$ dari jenis pisces (Fandeli, 2001).

Salah satu provinsi yang memiliki potensi besar di industri pariwisata adalah Yogyakarta.Yogyakarta menjadi magnet kunjungan wisatawan baik bagi wisatawan domestik maupun mancanegara. Berbagai potensi yang dimiliki Yogyakarta membuat provinsi ini memiliki lebih banyak pilihan jenis wisata mulai dari wisata budaya, belanja, religi, taman bermain, water park, hingga wisata minat khusus. Sehingga beberapa kabupaten yang ada saling berbenah untuk bersaing dalam memperbaiki dan membuka destinasi wisata sebagai upaya peningkatan pendapatan asli daerah (PAD).

Kabupaten Sleman adalah salah satu dari empat kabupaten yang ada di Daerah Istimewa Yogyakarta yang mulai membenahi berbagai potensi kepariwisataan yang ada, salah satunya dengan menciptakan jenis wisata dengan melihat potensi wisata yang ada ke arah wisata alam dan konservasi.

Potensi wisata yang baru berkembang dan membentuk jenis wisata yang mengarah pada wisata yang bertanggung jawab terhadap lingkungan di masa depan akan membentuk daya tarik tersendiri. Trend perkembangan dunia pariwisata mulai meninggalkan konsep pariwisata masal dan mengarah kepada konsep pariwisata lingkungan.Salah satu konsep yang mulai dilirik oleh komunitas lokal adalah Ekologi Wisata atau lebih dikenal dengan Ekowisata.Konsep ini lebih mengedepankan keaslian potensi kekayaan alam dan peran serta masyarakat setempat dibutuhkan.

Ekowisata yang terdiri dari kelompok kecil wisatawan, relatif mudah diorganisir oleh masyarakat sekitar selama menikmati daya tarik wisata di kawasantersebut, sehingga tidak terlalu menimbulkan dampak negatif seperti polusi suara maupun sampah. Selainitu pula, pengembangan ekowisata yang berbasis masyarakat merupakan peluang untuk mengembangkandestinasi wisata yang hampir tidak diketahui oleh wisatawan pada umumnya, dan akan mengurangidampak sosial budaya masyarakat tersebut.

Masyarakat lokal di salah satu padukuhan yaitu Klegung desa Donokerto kecamatan Turi kabupaten Sleman telah mencoba membuka suatu destinasi wisata yang mengarah pada konsep ekologi wisata.Hal ini dikarenakan adanya potensi aliran sungai Klegung yang membelah padukuhan tersebut.Keindahan alam daerah riparian sungai yang masih asri dan alami membuat masyarakat khususnya pemuda berinisiatif untuk membuka suatudestinasi wisata guna memberi manfaat baik secara ekonomi maupun keberlangsungan dan keberlanjutan ekosistem sungai.

Wisata Susur Sungai Klegung (Susu Glemer) merupakan nama yang kemudian diberikan untuk destinasi baru ini. Daya tarik wisata ini masih dalam tahap pengembangan, 
berkonsep sungai dengan habitat binatang dan tumbuhannyayang masih ada. Jika dilihat destinasi ini masih memiliki potensi lain sebagai atraksi wisata yangsesuai dengan konsep ekowisata. Minimnya sumber daya manusia serta tenaga ahli dibidang wisata, membuat destinasi ini dalam pengemasan paket wisatanya belum dapat berjalan secara maksimal. Seperti potensi kuliner atau makanan khas, atraksi budaya, kearifan lokal, serta potensi lain yang dapat dijadikan sebagai daya tarik untuk pengemasan paket wisatanya.

\section{LITERATUR REVIEW}

\section{Potensi Wisata}

Dalam kajian pariwisata potensi jika dilihat dari dominasi karakter kegiatan dan karakter ruang yang dimilikinya maka potensi wisata dapat diklafisikasikan menjadi potensi wisata alam, potensi wisata budaya, dan potensi wisata perkotaan( Avenzora, 2008). Sedangkan Menurut Soekadijo(1996) potensi pariwisata yang merupakan suatu modal nantinya menjadi daya tarik dan dikembangkan menjadi atraksi wisata ada tiga macam, yaitu : potensi alam, potensi kebudayaan, dan potensi manusia.

\section{Potensi Wisata Alam}

Potensi alam yang dimaksud adalah alam fisik (gua, sungai, danau, topografi yang menantang, dan pemandangan), fauna, dan floranya. Menurut Fandeli (2001) Pada dasarnya kegiatan wisata alam dapat dikelompokkan menjadi wisata alam (Ecotourism), wisata pertanian (Agrotourism), dan wisata pedesaan (Village Tourism). Model atraksi alam juga dapat berupa: pegunungan, dataran tinggi \& plateau, padang luas, sungai, air terjun, danau, pemandangan, laut, pantai, pulau, mata air panas, fenomena alam yang menarik, binatang, tumbuhan, ngarai/lembah, kawah, gua, payau/tanjung, cagar alam.

Potensi daya tarik wisata alam pada umumnya rawan pengrusakan, pemanfaatannya perlu wawasan lingkungan yang lestari, sehingga sumber daya alam dan ekosistem tetap menjadi daya tarik wisata yang diminati. Adanya potensi wisata alam sebagai objek daya tarik wisata diperlukan suatu inventarisasi guna mengetahui aktivitas yang sesuai dengan kawasan disuatu daerah seperti : taman nasional, suaka marga satwa, hutan wisata, taman wisata alam, taman hutan raya dan taman buru dengan pengembangan berbasis konservasi serta pemanfaatan kawasan untuk ekowisata( Triastuti, 2015). Daya tarik wisata dengan potensi alamiahnya dapat pula diciptakan dengan merekayasa suatu objek atau menawarkan suatu "peristiwa" yang sesuai dengan potensi sumber daya daerah, keunikan peristiwa serta sasaran dan kebutuhan pasar(Warpani, 2007).

Soekadijo (1996) dalam Warpani (2007) menggolongkan jenis pariwisata alam aktif maupun pasif menjadi lima golongan yakni: Melakukan kegiatan-kegiatan di alam terbuka, misalnya: berjemur di pantai, menyelam, berburu, panjat tebing. Menikmati suasana alam, seperti: menikmati keindahan alam, kesegaran iklim pegunungan, ketenangan alam pedesaan. Mencari ketenangan, melepaskan diri dari kesibukan rutin sehari-hari, beristirahat, tetirah. Menikmati "rumah kedua", menikmati tempat tertentu, tinggal di pesanggrahan (bungalow, vila) miliknya atau sewaan, atau mendirikan tempat berteduh sementara berupa tenda, atau menggunakan caravan. Melakukan widiawisata; alam menjadi studi, mempelajari flora atau fauna.

Menurut Triastuti (2015) Melalui potensi sumber daya alam yang ada, maka dapat dimanfaatkan sebagai pendidikan konservasi yang meliputi fasilitas dan kegiatan seperti :

sarana dan prasarana untuk kegiatan pendidikan mental dan konservasi sarana hunian, mess tempat menginap para wisatawan; sarana dan prasarana untuk kegiatan outbond, seperti sarana panjat tebing, susur sungai, fun ekologi; camping ground; pembibitan; jelajah hutan, dan pengamatan flora dan fauna; flying fox; 
cavetaria dan pusat Informasi; dan tempat Penjualan Souvenir.

\section{Potensi Flora}

Potensi flora terdiri dari keanekaragaman jenis merupakan salah satu aset wisata yang potensial, sebagai daya tarik untuk dikunjungi oleh wisatawan. Adapun kriteria kualitas keanekaragaman flora sebagai dasar pengukuran apakah bisa dikatakan berpotensi atau tidak yaitu sebagai berikut (Fandeli (2000), dikutip oleh Widowati, Tesis (2012) : skala 1 jumlah jenis < 5 jenis berarti buruk, skala 2 jumlah jenis 6 - 10 jenis berarti agak buruk, skala 3 jumlah jenis 11 - 20 jenis berarti sedang, skala 4 jumlah jenis 21 - 31 jenis berarti baik, dan skala 5 jumlah jenis > 31 jenis berarti sangat baik.

\section{Potensi Fauna}

Potensi fauna terdiri dari keanekaragaman jenis merupakan aset wisata yang potensial. Bisa sebagai daya tarik untuk dikunjungi oleh wisatawan. Adapun kriteria kualitas keanekaragaman fauna (Fandeli, 2000), dikutip oleh Widowati, Tesis (2012) yaitu : skala 1 jumlah jenis 1 - 2 jenis satwa berarti buruk, skala 2 jumlah jenis 3 - 5 jenis satwa agak buruk, skala 3 jumlah jenis 6 - 10 jenis satwa berarti sedang, skala 4 jumlah jenis 11 15 jenis satwa berarti baik, dan skala 5 jumlah jenis $>15$ jenis satwa berarti sangat baik.

\section{Potensi Kebudayaan}

Potensi kebudayaan disini adalah kebudayaan dalam arti luas, tidak hanya meliputi kebudayaan tinggi, tetapi juga meliputi adat istiadat dan segala kebiasaan yang hidup di tengah-tengah suatu masyarakat. Wisatawan ekowisata tidak hanya tertarik pada keindahan alam bebas tetapi juga pada aspek kebudayaan masyarakat lokal (local people) dan masyarakat adat/asli. Nilai-nilai warisan budaya, mencakup cagar alam, lanskap, bangunan prasejarah, arsitektur, seremoni, bahasa, dan seni tradisionil harus mampu dipelihara dalam kerangka aspek legal. Menurut Warpani (2007) kekayaan budaya daerah, upacara adat, busana daerah(yang menjadi bagian busana nasional), dan kesenian adalah potensi-potensi yang dapat dijadikan daya tarik wisata bila dikemas dan disajikan secara professional tanpa "merusak" nilai-nilai dan norma-norma budaya aslinya. Adapun untuk mengetahui potensi kebudayaan pada masyarakat menggunakan analisis deskripsi dengan menggambarkan keadaan budaya, adat istiadat maupun tradisi masyarakat.

\section{Potensi Sumber Daya Manusia(SDM)}

Pengembangan jasa ekowisata secara berkelanjutan pada dasarnya diarahkan kepada pengembangan modal manusia. Melalui keahlian, ketrampilan, dan krativitas, SDM menjalankan pengelolaan dalam jangka pendek maupun jangka panjang (Nugroho, 2011). Menurut Warpani (2007) manusia harus ditempatkan sebagai objek sekaligus subjek pariwisata, misalnya para penyadap nira (air bunga tal atau aren kelapa) adalah daya tarik yang dapat menjadi objek tontonan, namun sekaligus sebagai subjek pariwisata. Kenyataan bahwa manusia dapat menjadi atraksi wisata, akan tetapi kedudukannya tidak dapat direndahkan hingga kehilangan martabatnya sebagai manusia(Soekadijo 1996, dalam Warpani, 2007). Adapun untuk mengetahui potensi manusia yaitu menggunakan analisis deskripsi dengan menggambarkan kondisi, kegiatan masyarakat.

\section{Ekowisata}

Menurut Fandeli (2000) ekowisata juga merupakan suatu perpaduan dari berbagai minat yang tumbuh dari keperihatinan lingkungan, ekonomi, dan sosial. Kegiatan pengusahaan wisata ini dapat memberikan manfaat sebagai pendanaan kawasan konservasi, pembenaran ekonomi dalam perlindungan kawasan konservasi, sebagai alternatif mata pencaharian masyarakat lokal utuk mengurangi pemanfaatan sumberdaya alam yang berlebihan, sebagai pilihan dalam mempromosikan konservasi, serta sebagai dorongan dalam upaya konservasi yang khusus (Brandon (1996) dalam Avenzora (2008:11)). 
Selain itu menurut Heher (2003) dalam Damanik dan Weber ( 2006), ekowisata merupakan kegiatan wisata yang : secara aktif menyumbang kegiatan konservasi alam dan budaya; melibatkan masyarakat lokal dalam perencanaan, pengembangan, dan pengelolaan wisata serta memberikan sumbangan positif terhadap kesejahteraan mereka; dan dilakukan dalam bentuk wisata independen atau diorganisasi dalam bentuk kelompok kecil.

\section{Kriteria Pengembangan Ekowisata}

Kriteria dasar yang digunakan dalam pengembangan ekowisata adalah perencanaan pengembangan di daerah tujuan wisata, kawasan yang dapat dipakai objek daya tarik wisata yang merupakan faktor yang memiliki sifat dan prilaku spesifik di samping memiliki kerentanan ekosistem dalam memberikan atraksi alam (Triastuti 2015). Ekowisata diberi batasan sebagai bentuk dan kegiatan wisata yang bertumpu pada lingkungan dan bermanfaat secara ekologi, sosial dan ekonomi bagi masyarakat lokal serta bagi kelestarian sumberdaya alam dan pemanfaatan yang berkelanjutan.

Dalam pemilihan dan pengembangan lokasi ekowisata ada beberapa kriteria yang harus dipertimbangkan menurut Oka A Yoeti (2008) dan Masyarakat Ekowisata Indonesia(MEI) yaitu: tersedianya aksesibilitas yang memadai ke daerah tersebut; memberi peluang bagi pengembangan kegiatan sosial, ekonomi, dan seni budaya bagi masyarakat setempat; dapat saling mendukung bagi pengembangan pelestarian kawasan hutan bagi kepetingan hidup masyarakat yang tinggal dan hidup di sekitar kawasan ekowisata yang yang akan dikembangkan; daerah itu memiliki keunikan khusus yang tidak dijumpai di daerah lain; memiliki atraksi seni dan budaya yang unik dan berbeda dengan suku bangsa lain; adanya kesiapan masyarakat setempat untuk berpartisipasi dalam proyek yang akan dikembangkan; dan tersedianya sarana akomodasi, rumah makan, dan sarana pendukung lainnya.
Menurut Choy (1997) dalam Fandeli (2005) ada lima aspek utama agar ekowisata berkembang : adanya keaslian lingkungan alam dan budaya; keberadaan dan dukungan masyarakat; pendidikan dan pengalaman; keberlanjutan; dan kemampuan manajemen dalam pengelolaan ekowisata.

Ties (2000) dalam Damanik dan Weber (2006) Ekowisata dapat diidentifikasi melalui beberapa prinsip yaitu: mengurangi dampak negatif berupa kerusakan atau pencemaran lingkungan dan budaya lokal akibat kegiatan wisata; membangun kesadaran dan penghargaan atas lingkungan dan budaya di destinasi wisata, baik pada diri wisatawan, masyarakat lokal maupun pelaku wisata lainnya; menawarkan pengalamanpengalaman positif bagi wisatawan maupun masyarakat lokal melalui kontak budaya yang lebih intensif dan kerjasama dalam pemeliharaan atau konservasi DTW; memberi keuntungan finansial secara langsung bagi keperluan konservasi melalui kontribusi atau pengeluaran ekstra wisatawan; memberikan keuntungan finansial dan pemberdayaan bagi masyarakat lokal dengan menciptakan produk wisata yang mengedepankan nilai-nilai local; meningkatkan kepekaan terhadap situasi sosial, lingkungan dan politik di daerah tujuan wisata; dan menghormati hak asasi manusia dan perjanjian kerja, dalam arti memberikan kebebasan kepada wisatawan dan masyarakat lokal untuk menikmati atraksi wisata sebagai wujud hak azasi, serta tunduk pada aturan main yang adil dan disepakati bersama dalam pelaksanaan transaksi-transaksi wisata.

\section{Sungai}

Sungai merupakan saluran alami yang di dalamnya terdapat aliran air yang bermuara di danau atau di laut.Sungai juga melintasi berbagai jenis batuan dengan topografi yang bervariasi, maka sungai memiliki kesuburan yang dibutuhkan oleh biota (tumbuhan, hewan, maupun manusia), sehingga sungai dapat menjadi sumber kehidupan (Fandeli, 2000). Wisata sungai adalah kegiatan wisata yang daya tariknya bersumber dari potensi 
sungai. Dalam pengambangan aktivitas wisata sungai, ada banyak aktivitas yang dapat dilakukan, tergantung pada pengelolaan serta potensi yang dimiliki sungai. Aktivitas wisata yang memungkinkan di sungai seperti : air terjun, waduk, arung jeram, river tubing, dan susur sungai menggunakan perahu.

Menurut Fandeli (2001) sungai Klegung berdasarkan jumlah airnya dapat digolongkan sebagai sungai periodik, yaitu sungai yang pada musim hujan airnya besar bahkan dapat banjir, sedang pada musim kemarau airnya kecil.

\section{Pariwisata Berkelanjutan}

$\begin{array}{llr}\text { Hadiwijoyo } & \text { (2012) mendefinisikan } \\ \text { pariwisata } & \text { berkelanjutan } & \text { sebagai }\end{array}$
pembangunan kepariwisataan yang sesuai dengan kebutuhan wisatawan dengan tetap memperhatikan kelestarian, memberi peluang bagi generasi muda untuk memanfaatkan dan mengembangkannya berdasarkan tatanan sosial yang telah ada.

Dalam perspektif ekonomi, pembangunan berkelanjutan dimaksudkan untuk tidak mengurangi kapasitas produksi di masa mendatang. Sedangkan perkembangannya justru pariwisata berkelanjutan harus mempertimbangkan kebutuhan manusia di masa kini dan masa mendatang.

Adapun prinsip-prinsip pembangunan pariwisata berkelanjutan menurut Fandeli (2005) dapat dicapai bila dipenuhi kriteria: Keberlanjutan dengan kriteria kelestarian lingkungan dan sesuai dengan daya dukungnya. Keberlanjutan Sosial, yaitu: tidak terpengaruh dan terbawa oleh nlai-nilai sosial budaya wisatawan. Keberlanjutan Budaya, yaitu: budaya masyarakat menjadi daya tarik yang sangat kuat bagi wisatawan serta tidak mengalamai perubahan dalam kurun waktu panjang. Keberlanjutan dalam Ekonomi, yaitu: adanya peningkatan pendapatan masyarakat lokal, kawasan pariwisata, pemerintah, serta dapat menutup seluruh nilai untuk melakukan penanganan dampak negatif lingkungan sosial dan budaya.

\section{METODE}

Metode yang digunakan dalam penelitian ini adalah mixed method. Sumber data yang digunakan dalam penelitian ini yaitu data yang diambil dari lingkungan kawasan daya tarik wisata Sungai Klegung dan diluar kawasan yaitu organisasi dan instansi terkait. Adapun sumber data yang dipergunakan yaitu: data primer yaitu data yang diperoleh dari hasil wawancara, observasi dan data dari daya tarik wisata Susur Sungai Klegung Padukuhan Klegung; dan data sekunder yaitu data yang diperoleh berupa dokumentasi, penelitian Kelompok Studi Biologi Universitas Gadjah Mada, Balai Konservasi Sumber Daya Alam(BKSDA) Provinsi Yogyakarta, serta Desa Donokerto.

Dalam penelitian ini juga digunakan 32 sampel untuk diberikan kuesioner(Roscoe 1982 dalam Sugiyono 2011). Kuesioner diberikan kepada 32 orang wisatawan untuk mengetahui aktivitas atau atraksi wisata susur sungai apa yang mereka anggap berpotensi di daya tarik wisata Sungai Klegung dengan memperhatikan kriteria dan prinsip wisata alternatif. Kemudian kuesioner/angket yang telah diisi dikumpulkan guna dianalisis untuk mengetahui potensi atraksi wisata yang sesuai dengan Wisata Susur Sungai Klegung.

\section{HASIL DAN PEMBAHASAN}

\section{Aksesibilitas}

Aksesibilitas pariwisata adalah semua jenis sarana dan prasarana transportasi yang mendukung pergerakan wisatawan dari wilayah asal ke destinasi pariwisata maupun pergerakan di dalam wilayah destinasi pariwisata dalam kaitan dengan motivasi kunjungan wisata. Aksesibilitas sangat menentukan bagi wisatawan untuk melakukan sebuah perjalanan wisata. Jadi, apabila suatu destinasi wisata tersebut sudah memaksimalkan dalam hal akses maka ada kemungkinan besar suatu destinasi wisata tersebut akan sangat mengalami kemajuan dalam kunjungan wisatanya. 


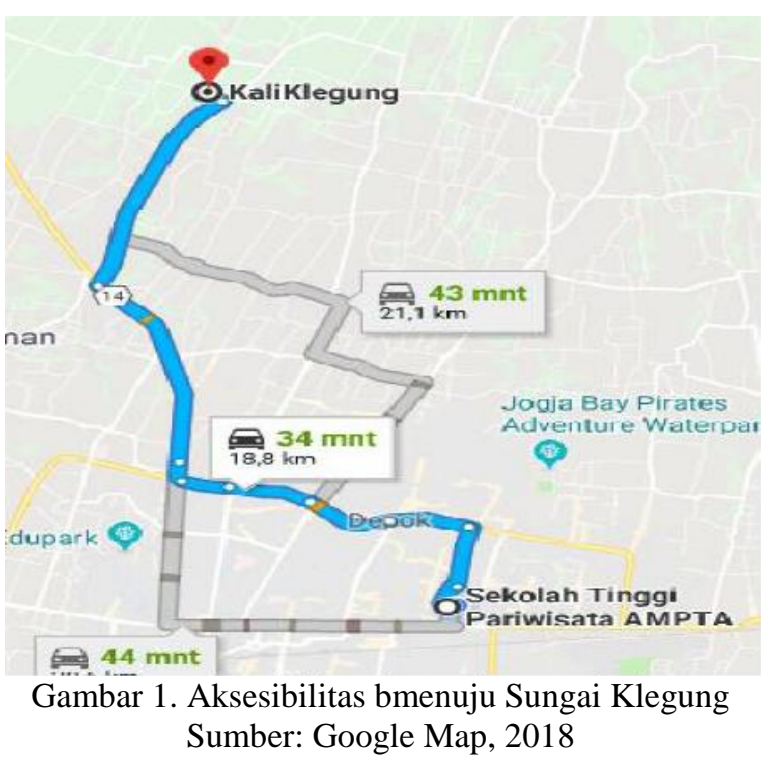

Padukuhan Klegung dapat diakses melalui Jl. Ringroad Utara, Jl. Magelang Purworejo, Jl. Magelang Yogyakarta, dan Jl. Turi.Kondisi jalan menuju lokasi sudah bagus dan mudah ditempuh. Padukuhan Klegung dapat ditempuh dengan menggunakan kendaraan pribadi, karena masih dalam proses pengembangan, sehingga untuk kendaraan umum belum dapat beroperasi menuju kawasan Padukuhan Klegung.

\section{Potensi Amenitas}

Amenitas adalah berbagai fasilitas yang dapat dimanfaatkan wisatawan selama berwisata di suatu destinasi. Amenitas dapat berupa fasilitas wisata seperti rumah makan, restoran, toko cinderamata, dan fasilitas umum seperti sarana ibadah, toilet, kesehatan, taman dan lain-lain.

Sungai Klegung merupakan suatu destinasi yang masih alami dan dikatakan masih baru, jadi untuk pembangunan dan pengadaan fasilitas belum terealisasikan sepenuhnya. Amenitas merupakan suatu hal yang dikatakan penting dalam suatu destinasi wisata, karena dengan ketersediaan fasilitas dapat memudahkan wisatawan yang berkunjung.

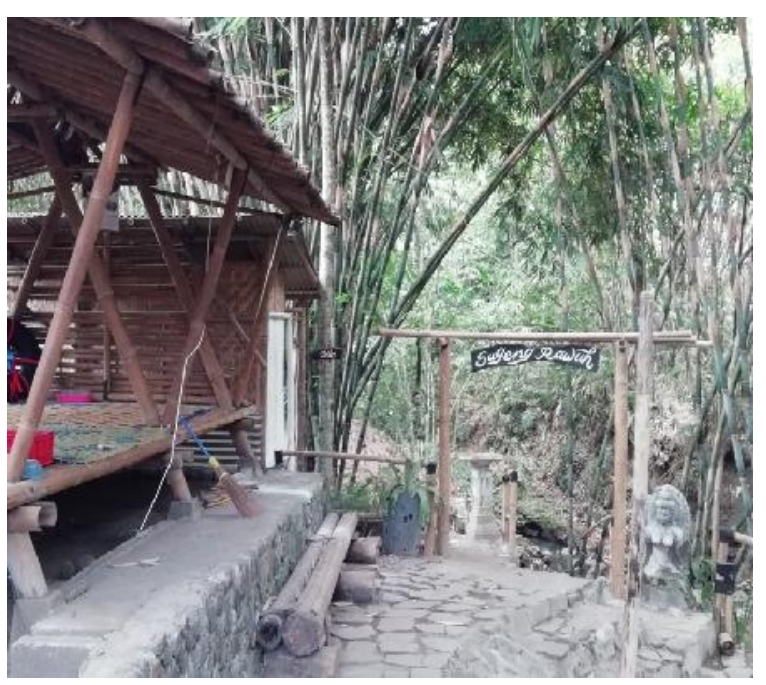

Gambar 2. Gazebo dan Toilet

Sumber: Data primer diolah, 2018

Fasilitas merupakan suatu pelayanan berupa sarana dan prasarana yang diberikan pengelola kepada wisatawan untuk melancarkan pelaksanaan fungsi dan kemudahan. Berdasarkan hasil observasi peneliti kondisi saat ini di Sungai Klegung mengenai amenitas yang ada dapat dikatakan minim sekali. Adapun amenitas yang sudah ada adalah satu buah Gazebo bambu, toilet dalam bentuk sederhana berbahan bambu, panggung terbuka, peralatan susur sungai, mushola atau masjid.

\section{Potensi Atraksi Wisata}

\section{Atraksi Wisata Alam}

Berdasarkan hasil obeservasi serta pengumpulan data dari berbagai sumber, bahwa di sungai Klegung memiliki potensi flora dan fauna yang cukup beragam sehingga merupakan suatu daya tarik yang dapat dijadikan sebagai potensi bagi pengembangan Ekowisata.

Data yang berhasil dikumpulkan oleh peneliti terdapat 50 jenis Flora yang terbagi ke dalam tanaman paku, tanaman atau tumbuhan bawah berupa rumput-rumputan, tanaman rakyat, tanaman perkebunan, dan tanaman bunga. Penulis juga berhasil mengumpulkan data ada sebanyak 43 fauna yang berada di Sungai Klegung yang terbagi kedalam kupukupu, serangga, burung serta berbagai spesies lain yang hidup di kawasan sungai Klegung. 


\section{Potensi Flora}

Wisata Sungai Klegung beserta kawasan sekitarnya, memiliki beragam potensi flora terutama jenis tanaman bambu, paku, tanaman hutan pinggir sungai, dan bunga.Tanaman hutan pinggir sungai dan tanaman perkebunan juga memiliki banyak jenis, terdapat puluhan jenis tanaman yang berada di kawasan pinggir sungai serta kawasan sekitarnya.

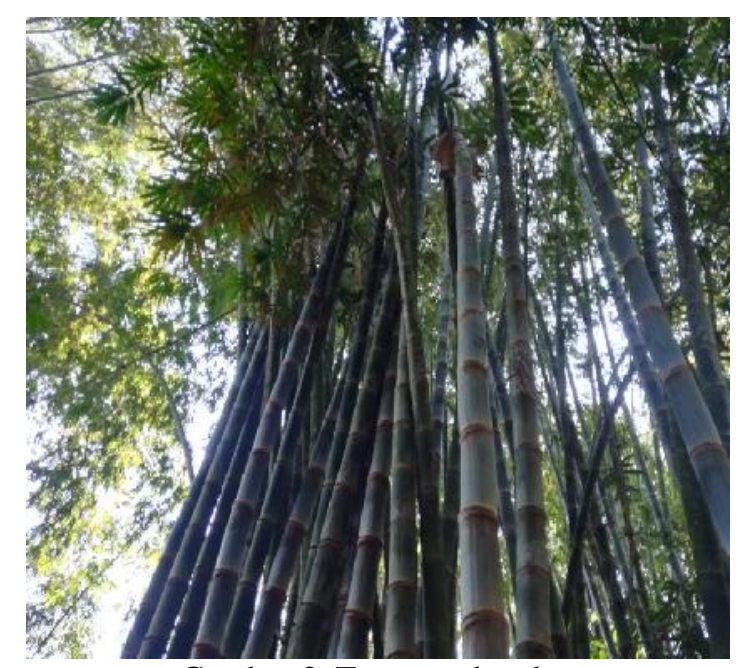

Gambar 3. Tanaman bambu

Sumber: Data primer diolah, 2018

Tanaman hutan rakyat yang menjadi andalan di Padukuhan Klegung umumnya yaitu Sengon, Bambu, dan Aren. Selain itu beberapa tanaman perkebunan juga mendominasi wilayah Klegung seperti salak Pondoh.

Selain itu flora yang terdapat pada wisata Sungai Klegung juga cukup beragam, data yang berhasil dikumpulkan melalui observasi penulis yaitu ada 15 spesies bunga serta 9 spesies tanaman bawah atau rumputrumputan. Beberapa tanaman yang ada di Sungai Klegung adalah merupakan tanaman yang ditanam oleh pengelola yang diambil di lingkungan perumahan warga untuk ditanam serta ditata di sungai Klegung. Tanaman bunga yang paling banyak yaitu jenis bunga kenikir sebanyak 3 spesies, dan pacar air sebanyak 2 spesies. Spesies tanaman bawah di dominasi oleh jenis irengan, rumput teki, Putri Malu.Berdasarkan hasil inventarisasi jenis flora yang ada, jelas bahwa objek wisata Susur Sungai Klegung sangat berpotensi untuk dikembangkan sebagai ekowisata. Berdasarkan hasil inventarisasi yang telah dilakukan dan mengacu pada teori menurut Fandeli (2000) bahwa jumlah flora yang terdata sebanyak 50 spesies yang artinya masuk ke dalam skala 5 (lima) yaitu > 31 spesies, sehingga masuk ke dalam kategori sangat baik. Data ini menggambarkan bahwa Sungai Klegung memiliki kekayaan keanekaragaman flora yang dimiliki, sehingga dapat menjadi daya tarik bagi wisatawan. Lebih tepatnya lagi wisatawan dapat melakukan berbagai kegiatan yang berkaitan dengan flora seperti pengamatan serta penelitian terhadap tanaman bambu, paku, dan pelestarian vegetasi kawasan mata air dengan aktivitas berupa tree adoption.

\section{Potensi Fauna}

Fauna yang dapat ditemui di Sungai Klegung serta kawasan sekitarnya berjumlah 43 spesies yang terdiri dari Burung (Aves), mamalia, reptilia, kupu-kupu (Lepidoptera), Amphibia, dan Insecta. Spesies yang paling banyak dijumpai yaitu burung dan serangga, berdasarkan data yang diperoleh dari hasil observasi penulis ada 14 spesies burung dan 10 spesies serangga yang dapat dijumpai di wilayah Sungai Klegung.

Salah satu fauna yang sering sekali dijumpai di berbagai wilayah sungai yang masih alami yaitu serangga cenggerek. Cenggerek ini akan mengeluarkan suara yang khas. Berdasarkan observasi, cenggerek ini akan berada ditepian sungai kemudian mengeluarkan bunyi antara siang hari sampai dengan sore hari. Adanya potensi serangga ini dapat menjadi daya tarik bagi Ekowisata di tengah semakin jarangnya habitat tepian sungai yang masih alami, sehingga diharapkan dapat menarik minat wisatawan yang berasal dari perkotaan.

Berdasarkan hasil inventarisasi jenis fauna yang ada, objek wisata Sungai Klegung sangat berpotensi untuk dikembangkan sebagai Ekowisata. Berdasarkan hasil inventarisasi yang telah dilakukan dan mengacu pada teori menurut Fandeli (2000) 
bahwa jumlah fauna yang terdata sebanyak 53 spesies yang artinya masuk kedalam skala 5 (lima) yaitu > 15 spesies, sehingga masuk kedalam kategori sangat baik. Data ini menggambarkan bahwa Sungai Klegung memiliki kekayaan keanekaragaman fauna, sehingga dapat menjadi daya tarik bagi wisatawan. Lebih tepatnya lagi wisatawan dapat melakukan berbagai kegiatan yang berkaitan dengan fauna seperti pengamatan serangga , pengamatan serta penelitian terhadap kupu-kupu dan ngengat malam, dan bird watching bagi jenis-jenis burung yang ada.

\section{Atraksi Wisata Budaya}

Potensi kebudayaan yang ada di Desa Donokerto khususnya wilayah penelitian yaitu padukuhan Klegung layak untuk menjadi sebuah warisan budaya yang harus dilestarikan guna menambah kekayaan budaya Indonesia pada umumnya, serta dapat menjadi sebuah atraksi yang bernilai tinggi bagi terwujudnya suatu daerah tujuan wisata berbasis Ekologi Wisata.

Kebudayaan merupakan senjata yang paling ampuh, mengapa kita harus mempertahankan kebudayaan yang ada, hal ini dikarenakan kebudayaan merupakan alat untuk mempersatukan warga yang ada di Desa Donokerto yang memiliki bermacam-macam agama. Apapun kepentingan yang ada, jika kita mempersatukan menggunakan budaya seperti upacara adat, maka sudah tidak ada lagi perbedaan di antara mereka (R. Waluyo Jati, S.T, Kepala Desa Donokerto).

\section{Merti Kali}

Setiap bulan Sapar (tahun hijriah) warga Padukuhan Klegung menggelar tradisi Saparan.Tradisi ini rutin dilaksanakan setiap tahun, upacara adat ini merupakan wujud syukur kepada Tuhan Yang Maha Esa karena munculnya sumber air atau mata air. Prosesi dari ritual Saparan ini dilakukan di mata air yang terletak disepanjang aliran sungai Klegung.

\section{Suranan}

Upacara ini juga dilaksanakan setiap satu tahun sekali. Ada dua kegiatan dalam suranan yang pertama yaitu Baritan yang dilaksanakan malam satu Sura yang sesajinya sama dengan Saparan akan tetapi lebih memiliki ciri khas yaitu wajib adanya ketupat, tempe, lepet, golong (semua berbahan dari ketan).

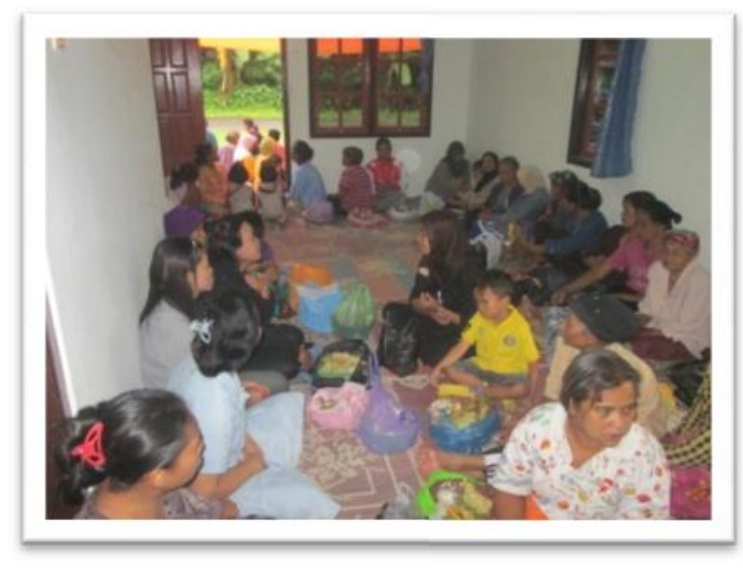

Gambar 4. Atraksi Budaya Suronan Sumber: Data primer diolah, 2018

Baik Saparan dan Suranan keduanya wajib membawa kupat yang jumlahnya wajib menghitung jumlah jiwa yang ada di keluarga, jika dalam keluarga ada 5 maka setiap orang harus membawa kupat sebanyak 5 serta dilebihkan 1 kupat untuk dikumpulkan ke panitia, kemudian kupat yang dikumpulkan akan dibagiakan kepada orang atau warga yang menghadiri. Demikian juga dengan kupat yang dibawa akan ditukarkan kepada kupat orang lain.

\section{Santi Laras}

Selain dua kebudayaan di atas ternyata di padukuhan Klegung masih ada satu lagi potensi budaya yang dapat dijadikan atraksi untuk dipentaskan dihadapan wisatawan. Potensi budaya ini adalah seni musik yang diberi nama Santi Laras. Santi Laras ini adalah permainan musik yang memadukan alat musik gamelan dengan rebana. Seminggu sekali setiap hari kamis (malam Jumat) bapak-bapak dan pemuda rutin melakukan latihan seni musik ini.

\section{Potensi Sumber Daya Manusia}

Berdasarkan hasil observasi dilapangan lainnya didapatkan bahwa masyarakat di Padukuhan Klegung Desa Donokerto cukup berpotensi, hal ini dapat dilihat dari aktivitas 
kesehariannya yang tercermin dalam berbagai kegiatan menarik dari mata pencaharian dan kuliner khas dari warganya, seperti para petani penggarap sawah, petani salak pondoh, pembuatan keripik salak dan dodol salak. Aktivitas tersebut merupakan aset yang sangat berharga bagi masyarakat Dusun Klegung, Desa Donokerto untuk dipertahankan sebagai aset khususnya pariwisata. Sumber daya manusia tersebut termasuk kedalam potensi yang dapat dikembangkan sebagai daya tarik wisata bagi Susur Sungai Klegung atau sebagai Desa Wisata nantinya.

\section{Olahan Buah Salak Pondoh}

Di Padukuhan Klegung ada olahan buah salak berupa keripik dan dodol salak.Olahan berbahan buah salak ini adalah merupakan suatu alternatif olahan makanan dengan memanfaatkan bahan yang ada di Dusun Klegung.

Kreatifitas Olahan makanan ini muncul dan kemudian berkembang dikarenakan pada masa panen raya salak yang biasanya jatuh pada bulan Oktober - Februari harga salak ditingkat petani sangat rendah. Dengan adanya kreatifitas yang muncul ini ternyata mampu menggairahkan petani salak pondoh karena pada saat panen raya tidak kuatir salaknya tidak akan laku. Salak pondoh oleh warga Padukuhan Klegung kemudian diolah menjadi makanan dalam bentuk keripik salak pondoh, dodol salak, dan manisan salak.

\section{Rempeyek Kacang}

Produk rumah tangga lainnya yang dibuat oleh ibu-ibu Padukuhan Klegung adalah rempeyek kacang, yang ternyata dengan teknik pembuatan yang tepat mampu dihasilkan rempeyek yang gurih dan renyah.

\section{Outbond}

Kreatifitas yang muncul dari pengelola Sungai Klegung adalah adanya aktifitas Outbond. Outbond ini ternyata dapat digunakan sebagai pelengkap atraksi susur sungai, dan pada waktu aliran sungai kecil dapat digunakan supaya aktifitas kegiatan kunjungan wisatawan tetap ada.

\section{Motif, Aktivitas dan Persepsi Pengunjung Sungai Klegung.}

Motif wisata merupakan salah satu hal yang mendasari suatu perjalanan akan dilakukan, berbeda latar belakang budaya akan menghasilkan perbedaan pula dalam motif berwisata. Mengetahui motif berwisata dapat menjadi suatu masukan bagi pengembangan suatu objek wisata, sehingga dalam penentuan atraksi wisata sesuai dengan konsep serta kondisi yang ada.

Berdasarkan hasil kuesioner yang disebarkan kepada 32 pengunjung menunjukan jika motif berkunjung ke Sungai Klegung sebagian besar mengetahui Sungai Klegung dari teman. Frekuensi kunjungan sebanyak satu kali, serta rata-rata mengunjungi Sungai Klegung bersama teman. Para pengunjung banyak yang datang dengan tujuan bermacam-macam seperti menikmati suasana tenang dan nyaman, menikmati keunikan flora dan fauna, akan tetapi tujuan yang paling banyak yaitu pendidikan atau melakukan penelitian, hal ini dibuktikan dengan persentase sebanyak $25 \%$.

\section{Pengemasan Atraksi Wisata Sungai Klegung}

Dengan melihat karakteristik, motif, dan aktivitas, maka dari hasil kuesioner terhadap kesesuaian atraksi wisata alam yang mengarah pada kegiatan ekologi wisata dapat dilakukan penentuan atraksi melalui penilaian potensi berdasarkan skor. Skor yang diperoleh dari kuesioner akan dinilai menggunakan sistem penilaian dari Arikunto yang telah dimodifikasi. 
Tabel 1

Hasil tanggapan responden (wisatawan) terhadap wisata alam melalui pendekatan atraksi ekowisata yang diinginkan

\begin{tabular}{|c|c|c|c|}
\hline \multirow[t]{2}{*}{ NO } & \multirow[t]{2}{*}{ Jenis Aktivitas/ atraksi Ekowisata } & \multicolumn{2}{|c|}{ Kategori Jawaban } \\
\hline & & Ya & Tidak \\
\hline 1 & Mengadopsi Pohon (Tree Adoption) & 31 & 1 \\
\hline 2 & Susur sungai serta pengamatan terhadap Keragaman Flora dan Fauna & 30 & 2 \\
\hline 3 & Belajar Membudidayakan tanaman salak pondoh & 32 & 0 \\
\hline 4 & Adanya kegiatan outbond, fun games dan camping ground & 27 & 5 \\
\hline 5 & Wisatawan disambut dengan tarian tradisional & 29 & 3 \\
\hline 6 & Mempelajari kebudayaan komunitas lokal & 29 & 3 \\
\hline 7 & $\begin{array}{l}\text { Menikmati paket wisata yang ikut berkontribusi terhadap kegiatan sehari-hari } \\
\text { warga }\end{array}$ & 30 & 2 \\
\hline 8 & Membuat olahan berbahan dasar salak & 25 & 7 \\
\hline 9 & Wisata minat khusus tinggal bersama warga & 27 & 5 \\
\hline 10 & Jelajah desa dengan menggunakan motor trail & 15 & 17 \\
\hline
\end{tabular}

Sumber: Data Primer (2018)

Berdasarkan hasil jawaban responden kurang memperhatikan pendekatan ekowisata sebanyak 32 orang yang dimintai yaitu menjelajahi desa menggunakan motor pendapatnya menggunakan kuesioner, dari 8 Trail juga terbukti tidak diminati oleh atraksi yang menggunakan pendekatan responden untuk wilayah Sungai Klegung. ekologi wisata, rata-rata responden Selain itu responden juga tertarik dengan memberikan penilaian setuju dengan skor adanya fasilitas outbond sebagai alternatif diatas 27. Hal ini membuktikan bahwa jenis wisata alam aktif.

responden memiliki keinginan terhadap Dengan menggunakan Sistem penilaian dari atraksi yang menggunakan pendekatan buku Arikunto yang telah dimodifikasi, konsep ekowisata.Selain itu peneliti dengan sengaja memasukkan satu atraksi yang

Tabel 2.

Sistem penilaian potensi wisata alam melalui pendekatan atraksi ekowisata yang diinginkan

\begin{tabular}{clcc}
\hline No & \multicolumn{1}{c}{ Jenis Aktivitas Ekowisata } & Nilai & \multicolumn{1}{c}{ Kategori } \\
\hline 1 & Mengadopsi Pohon (Tree Adoption) & 31 & Sangat Berpotensi \\
2 & Tracking serta pengamatan terhadap Keragaman Flora dan Fauna & 30 & Sangat Berpotensi \\
3 & Belajar Membudidayakan tanaman salak pondoh & 32 & Sangat Berpotensi \\
4 & Adanya kegiatan outbond, fun games dan camping ground & 27 & Sangat Berpotensi \\
5 & Wisatawan disambut dengan tarian tradisional & 29 & Sangat Berpotensi \\
6 & Mempelajari kebudayaan komunitas lokal & 29 & Sangat Berpotensi \\
7 & Menikmati paket wisata yang ikut berkontribusi terhadap & 30 & Sangat Berpotensi \\
& kegiatan sehari-hari warga & & \\
8 & Membuat olahan berbahan dasar salak & 25 & Sangat Berpotensi \\
9 & Wisata minat khusus tinggal bersama warga & 27 & Sangat Berpotensi \\
10 & Jelajah desa dengan menggunakan motor trail & 15 & Kurang Berpotensi \\
\hline
\end{tabular}

Sumber: Data Primer (2018)

Berdasarkan hasil penilaian dengan skor menunjukkan bahwa jenis aktivitas atau paket wisata berupa tree adoption atau mengadopsi pohon menunjukkan nilai sebesar 31. Nilai tersebut termasuk kedalam kategori sangat berpotensi, aktivitas ini juga sesuai dengan salah satu prinsip Ekowisata yang dikemukakan oleh Ties (2000), yaitu dapat menawarkan pengalaman-pengalaman positif bagi wisatawan maupun masyarakat lokal dalam pemeliharaan atau konservasi Daerah Tujuan Wisata (DTW). Dengan 
adanya suatu aktivitas yang dapat menjaga vegetasi di sekitar sungai Klegung, diharapkan objek wisata ini dapat menjadi wisata yang berkelanjutan, serta bagi warga dapat terus terpenuhi kebutuhan terhadap air dari mata air yang muncul di pinggir sungai Klegung.

Tracking serta melakukan pengamatan terhadap keragaman flora dan fauna yang berada di wilayah Sungai Klegung memperoleh nilai sebesar 30. Dengan sistem penilaian yang telah dilakukan, nilai tersebut termasuk kedalam kategori sangat berpotensi. Berdasarkan wawancara dengan salah seorang pemandu tracking bapak Kelik Sugiarto pada tanggal 27 Juli beliau mengatakan :

Sepanjang jalur tracking yang akan dilalui biasanya dapat kita temui berbagai jenis hewan seperti : burung hantu, tupai, luwak, kucing. Selain itu ada banyak tanaman berkayu di sepanjang jalur tracking yaitu : sengon, beringin, kelapa, aren, sonokeling, bambu dan masih banyak lagi.

Belajar membudidayakan salak pondoh merupakan aktivitas yang diminati oleh responden yaitu dengan nilai sebesar 32 .Berdasarkan sistem penilaian nilai tersebut berkategori sangat berpotensi. Salak yang berada diwilayah Klegung sendiri cukup banyak.

Musik tradisional (Santi Laras) sebagai musik penyambutan bagi wisatawan, hasil kuesioner menunjukkan nilai sebesar 27.Nilai tersebut berdasarkan sistem penilaian berkategori sangat berpotensi.Musikini merupakanmusikkhas yang hanya ada di Padukuhan Klegung.

Selain pertunjukan musik Santi Laras, mempelajari budaya komunitas lokal juga menempati nilai sebasar 29.Nilai tersebut berdasarkan sistem penilaian berkategori sangat berpotensi. Mempelajari kebudayaan komunitas lokal menjadi sangat penting bagi DTW yang akan mengusung konsep Ekowisata. Hal ini sesuai dengan Salah satu konsep dasar dari Ekowisata menurut form 2004, yaitu : Perjalanan wisata yang menaruh perhatian besar pada lingkungan alam dan budaya lokal. Konsep ini mengajarkan bahwa wisatawan banyak belajar dari masyarakat lokal, bukan sebaliknya menggurui masyarakat, konsep ini juga memberikan kesempatan bagi masyarakat agar dapat mempertunjukkan upacara dan pertunjukan yang sudah dimiliki masyarakat setempat.

Mengikuti aktivitas harian warga seperti: Bertani, memelihara kebun salak pondoh, berdasarkan kuesioner memperoleh nilai sebesar 30. Nilai tersebut berdasarkan sistem penilaian berkategori sangat berpotensi.Dengan adanya suatu paket atraksi berupa wisatawan mengikuti aktivitas harian warga maka sudah sesuai dengan salah satu prinsip Ekowisata menurut Ties 2000, yaitu meningkatkan kepekaan terhadap situasi sosial, lingkungan dan politik di daerah tujuan wisata.

Membuat olahan makanan berbahan dasar salak pondoh bersama warga, dari hasil kuesioner memperoleh nilai sebasar 32.Nilai tersebut berdasarkan sistem penilaian berkategori sangat berpotensi.Adapun dengan adanya jenis paket wisata berupa membuat makanan berbahan dasar salak pondoh bersama warga diharapkan wisatawan mampu membeli hasil yang telah mereka buat sebagai bentuk apresiasi. Hal ini sesuai dengan salah satu prinsip Ekowisata menurut Ties 2000, yaitu : memberi keuntungan finansial dan pemberdayaan masyarakat lokal dengan menciptakan produk wisata yang mengedepankan nilainilai lokal.

Wisata minat khusus tinggal bersama warga, berdasarkan hasil kuesioner memperoleh nilai sebesar 25.Nilai tersebut berdasarkan sistem penilaian berkategori sangat berpotensi. Adanya paket wisata seperti tinggal bersama warga telah sesuai dengan konsep dasar Ekowisata nomor 2 menurut From 2004, yaitu : wisata yang mengutamakan penggunaan fasilitas seperti akomodasi, transportasi yang dikelola oleh masyarakat lokal. Selain itu lebih spesifik akomodasi tersebut bukan perpanjangan dari hotel internasional, makanan yang 
ditawarkan bukan berbahan baku impor, serta menggunakan jasa pemandu lokal.

Jelajah desa menggunakan motor trail, hasil kuesioner menunjukkan nilai sebesar 15 . Nilai tersebut berdasarkan sistem penilaian berkategori kurang berpotensi. Dengan kurangnya minat responden terhadap jenis aktivitas ini maka sesuai dengan prinsip Ekowisata bahwa jelajah desa menggunakan motor trail akan membawa dampak kurang baik terhadap lingkungan. Motor akan mengeluarkan suara bising serta dapat mengganggu topografi. Hal ini juga sesuai dengan prinsip Ekowisata menurut Ties 2000, bahwa Ekowisata harus dapat mengurangi dampak negatif berupa kerusakan atau pencemaran lingkungan dan budaya lokal akibat kegiatan wisata.

Fasilitas kegiatan Out bond seperti : Susur sungai, Fun ekologi, Camping ground, hasil kuesioner menunjukkan nilai sebesar 27. Nilai tersebut berdasarkan sistem penilaian berkategori sangat berpotensi. Adanya fasilitas tersebut menurut Triastuti 2015, dapat mendukung kegiatan serta pedidikan konservasi.

Berdasarkan data karakteristik pengunjung menunjukkan bahwa usia pengunjung ratarata adalah antara 16 -20 tahun sebanyak $46,87 \%$, hal ini membuktikan pengunjung didominasi dengan usia muda serta diperlukannya fasilitas kegiatan out bond.

Berdasarkan potensi-potensi yang ada, maka menurut Choy (1997) dalam Fandeli (2005) ada lima aspek utama agar potensi ekowisata yang ada di Padukuhan Klegung dapat berkembang :

\section{Adanya Keaslian Lingkungan Alam dan Budaya.}

Sungai Klegung merupakan wisata alam yang memiliki pemandangan alam yang masih sangat asri. Dengan minimnya modal membuat pengembangan tidak berdasarkan pembangunan yang merubah tatanan lingkungan dan topografi lahan yang ada, sehingga keaslian masih dapat dipertahankan melalui pembangunan yang menjunjung tinggi nilai-nilai kearifan lokal seperti penggunaan pohon bambu serta bahan lainnya yang mudah ditemukan dilingkungan Sungai Klegung. Demikian dengan budaya masyarakat yang tetap dilestarikan seperti adanya kesenian berupa Musik Santi Laras dan upacara adat (Merti Kali, Suranan).

\section{Masyarakat Sadar Wisata}

Masyarakat yang telah sadar dengan potensi kepariwisataan yang ada juga merupakan modal utama Sungai Klegung dalam pengembangan ekowisata kedepan. Masyarakat dalam hal ini merupakan pengelola yang menjadi fokus utama sehingga pengembangan dalam jangka pendek, menengah, serta panjang merupakan bagian terpenting dalam kesiapan SDM yang ada. Perlu adanya modal SDM yang kuat melalui pendampingan atau pelatihan dari dinas serta lembaga terkait yang dapat menjamin keberlangsungan dalam pengembangan Sungai Klegung kedepan.

\section{Pendidikan dan Pengalaman.}

Berdasarkan data dari Desa tahun 2017 bahwa pendidikan dari warga Padukuhan di dominasi oleh SD $(25,17 \%)$, SMP $(21,89 \%)$, dan SMU $(33,96 \%)$. Selain itu mata pencaharian didominasi oleh pegawai swasta dan petani sebesar 61,57 \% yang berarti bahwa masyarakat sebagai pengelola minim pengalaman serta masih cukup rendahnya pendidikan. Perlu dilakukannya pendampingan dari berbagai pihak yang memiliki kemampuan dalam pengembangan ekowisata, sehingga ekowisata ke depan dapat terwujud.

\section{Keberlanjutan.}

Masyarakat sebagai pengelola merupakan kunci utama dari keberlanjutan destinasi kedepan.Sehingga berbagai aturan atau kebijakan perlu dibuat agar konsep berkelanjutan seperti keberlanjutan lingkungan, sosial, budaya, serta ekonomi masyarakat sendiri dapat berjalan sesuai dengan prinsip pembangunan kepariwisataan. Banyak hal yang bisa diterapkan dalam konsep keberlanjutan seperti dengan membuat suatu atraksi wisata yang memanfaatkan potensi kebudayaan sebagai 
sumber pendanaan bagi kegiatan kebudayaan masyarakat.

\section{Kemampuan Manajemen Pengelolaan Ekowisata.}

Dengan potensi-potensi yang ada, maka agar ekowisata kedepan dapat terwujud serta berkembang akan ditentukan dengan kemampuan manajemen dalam pengelolaan. Masyarakat kembali menjadi fokus utama agar pengembangan dapat berjalan sesuai dengan konsep ekowisata. Dinas pariwisata diperlukan dalam pendampingan, sebagai dinas yang memiliki kewenangan dalam perencanaan pengembangan kepariwisataan yang ada di Kabupaten Sleman.

\section{SIMPULAN}

Berdasarkan hasil penelitian yang dilakukan potensi yang ada di wilayah Padukuhan Klegung, terbagi kedalam Potensi Aksesibilitas, Potensi Amenitas, dan Potensi Atraksi Wisata yang meliputi: atraksi wisata alam melalui pendekatan atraksi Ekowisata serta Flora dan Fauna, atraksi wisata budaya, dan atraksi wisata buatan. Bedasarkan teori yang dikemukaan Oka A Yoeti (2008) dan Masyarakat Ekowisata Indonesia (MEI) bahwa kriteria pengembangan ekowisata yaitu memiliki keunikan yang tidak dijumpai di daerah lain, memiliki atraksi seni dan budaya yang unik dan berbeda dengan suku bangsa lain, dan adanya kesiapan masyarakat setempat untuk berpartisipasi, sehingga Padukuhan Klegung telah masuk ke dalam kriteria yang dibutuhkan bagi pengembangan ekowisata dengan berbagai potensi yang dimilikinya, antara lain:

\section{Potensi Atraksi Wisata Alam}

Potensi flora dan fauna yang melingkupi wilayah penelitian Sungai Klegung ada 50 spesies flora serta 43 spesies fauna yang berhasil penulis data.Flora terbagi kedalam tanaman paku, tanaman atau tumbuhan bawah berupa rumput-rumputan, tanaman hutan rakyat, tanaman perkebunan, dan tanaman bunga. Sedangkan fauna terbagi kedalam kupu-kupu (lepidoptera), burung
(Aves), serangga, ikan serta berbagai spesies lain yang hidup dikawasan sungai Klegung. Berdasarkan hasil inventarisasi jumlah flora sebanyak 50 spesies dan mengacu pada teori Fandeli (2000) bahwa jumlah tersebut masuk kedalam skala 5 (lima) yaitu > 31 spesies, sehingga berkategori sangat baik. Demikian juga dengan fauna, berdasarkan hasil inventarisasi jumlah fauna sebanyak 43 spesies dan mengacu pada teori Fandeli (2000) bahwa jumlah tersebut masuk kedalam skala 5 (lima) yaitu > 15 spesies, sehingga berkategori sangat baik. Pengunjung dapat melakukan hal-hal berkaitan dengan konservasi, pengamatan dan penelitian baik bagi flora ataupun fauna yang ada.

Pengunjung yang datang ke Sungai Klegung sebagian besar belum banyak berkontribusi terhadap daya tarik wisata ini.Akan tetapi dengan melihat hasil kuesioner yang diisi oleh wisatawan menunjukkan adanya minat wisatawan terhadap atraksi wisata alam yang menggunakan pendekatan Ekowisata sebagai pengembangan daya tarik wisata. Diantara kegiatan tersebut sebanyak 32 orang responden yang dimintai pendapatnya menggunakan kuesioner, dari 8 atraksi yang menggunakan pendekatan ekologi wisata, rata-rata responden memberikan penilaian setuju dengan skor diatas 27 yang berarti sangat berpotensi untuk dikembangkan di destinasi Sungai Klegung.

\section{Potensi Atraksi Budaya}

Kebudayaan dari wilayah penelitian Padukuhan Klegung sangat unik, dibagi menjadi seni musik, upacara adat,dan kegiatan religi. Upacara adat yang dimiliki merupakan acara tahunan yang sangat sakral bagi komunitas lokal, diantaranya yaitu Merti Kali dan Suranan. Diantara upacara adat tersebut Merti Kali merupakan upacara yang sangat unik serta tidak terdapat di daerah lain dikarenakan prosesi serta syarat yang diharuskan dalam melakukan upacara tersebut, sehingga menjadi salah satu acara tahunan yang sangat berpotensi untuk dikembangkan sebagai atraksi ekowisata.

Potensi Sumber Daya Manusia 
Potensi sumber daya manusia yang ada seperti petani sawah dan salak pondoh, peternak, kuliner khas olahan salak pondoh dan pembuat rempeyek kacang. Petani salak pondoh menjadi perhatian khusus peneliti karena tidak banyak daerah yang menjadi penghasil salak pondoh

Melihat berbagai potensi yang ada, jelas bahwa Padukuhan Klegung dengan sungai Klegungnya sangat berpotensi untuk dikembangkan sebagai daya tarik wisata yang menggunakan konsep Ekowisata. Dengan potensi yang dimiliki, partisipasi dan semangat masyarakat menjadikan modal penting bagi pengembangan destinasi Ekowisata kedepan.

Sebagai sumbangan pemikiran, agar penelitian ini dapat memberikan manfaat, baik bagi pengelola Susur Sungai Klegung, penelitian selanjutnya, Desa Donokerto serta Dinas Pariwisata Kabupaten Sleman, ada beberapa rekomendasi yang dapat disampaikan peneliti adalah sebagai berikut :

Bagi penelitian selanjutnya, perlu adanya ketelitian dalam pendataan potensi terkait keanekaragaman hayati. Maka dengan data potensi keanekaragaman hayati, potensi SDM, Kebudayaan dan Atraksi yang sesuai diharapkan ada penelitiaan terkait strategi pengembangan Wisata Susur Sungai Klegung.

Dalam pengelolaan objek wisata yang akan menggunakan konsep Ekowisata diperlukan Sumber Daya Manusia yang benar-benar siap serta mengerti, maka diperlukan suatu pendampingan baik dari Dinas terkait dalam hal ini Dinas Pariwisata Kabupaten Sleman atau dari institusi yang memiliki fokus terhadap pariwisata.

Pemerintah khususnya Dinas Pariwisata perlu melakukan penguatan kompetensi sumber daya manusia melalui pelatihan seperti pelatihan guiding, kuliner, souvenir, serta kesiapan homestay, sehingga masyarakat lebih siap dalam mengembangkan daya tarik wisata.

Perlu adanya penetapan carrying capacity (Daya Dukung Lingkungan) bagi pengembangan daya tarik wisata alam agar tidak terjadi kerusakan terhadap keindahan yang dimiliki oleh daya tarik wisata Susur Sungai Klegung.

\section{UCAPAN TERIMA KASIH}

Penulis mengucapkan terimakasih kepada berbagai pihak yang telah berkontribusi terhadap penelitian ini. Terutama kepada Kopertis Wilayah V yang telah memberikan bantuan dana hibah penelitian bagi dosen pemula.

\section{REFERENSI}

Arikunto, S. (2010). Prosedur Penelitian, Suatu Pendekatan Praktek, Edisi Revisi . Jakarta: Rineka.

Arikunto, S. (2005). Dasar-Dasar Evaluasi Pendidikan. Jakarta: Bumi Aksara.

Avenzora, R. (2008). Ekoturisme Teori dan Praktek. Aceh: BRR NAD-Nias.

Damanik, J \&Weber, H.F. (2006). Perencanaan Ekowisata:dari Teori ke Aplikasi. Yogyakarta : Penerbit ANDI bekerja sama dengan Pusat Studi Pariwisata (PUSPAR) UGM.

Fandeli, C \& Mukhlison. (2000). Pengusahaan Ekowisata. Yogyakarta: Fakultas Kehutanan Universitas Gadjah Mada.

Fandeli, C. (2001). Dasar-Dasar Manajemen, Kepariwisataan Alam. Lyberty Offset. Yogyakarta.

Fandeli, C. (2005). Pengembangan Ekowisata Berbasis Konservasi di Taman Nasional. Yogyakarta: Fakultas Kehutanan Universitas Gadjah Mada.

Hadiwijoyo, S.S. (2012). Perencanaan Pariwisata Pedesaan Berbasis 
Masyarakat, Sebuah Pendekatan

Konsep. Yogyakarta: Graha Ilmu.

Nugroho, I. (2011). Ekowisata dan Pembangunan Berkelanjutan. Yogyakarta: Pustaka Pelajar.

Soekadijo, R.G. (1996). Anatomi Pariwisata. Jakarta: Gramedia Pustaka Utama.

Triastuti, I. (2015). Model Ekowisata, Dalam Perspektif Hukum Konservasi Sumberdaya Alam Hayati dan Ekosistemnya. Bogor: Uika Press.

Warpani, S.P \& Warpani, I.P. (2007). Pariwisata, dalam tata ruang wilayah. Bandung: ITB.

Yoeti, O.A. (2008). Perencanaan \& Pengembangan Pariwisata. Jakarta: PT Pradnya Paramita.

Widowati, S. (2012). Kajian Potensi dan Evaluasi Penerapan Prinsip - Prinsip dan Kriteria Ekowisata di Kawasan Taman Wisata Alam Kawah Ijen, Desa Taman Sari, Kabupaten Banyuwanyi.Denpasar : Universitas Udayana.

\section{BIODATA PENULIS}

Arif Dwi Saputra, merupakan dosen tetap di Sekolah Tinggi Pariwisata AMPTA Yogyakarta.

Id Scholar:

https://scholar.google.co.id/citations?hl=id\& user $=$ wYNVW3UAAAAJ 